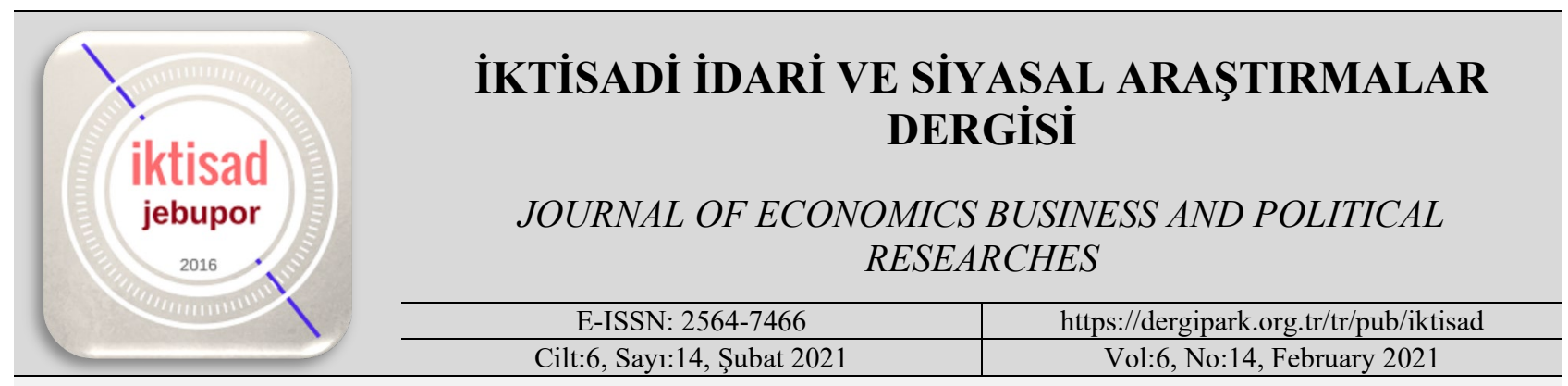

\title{
Çevreci Değerin Tekrar Satın Alma Üzerindeki Etkisinde Kurumsal Çevreci İmajın Aracı Rolü: Havayolu Yolcuları Üzerine Bir Araştırma*
}

\author{
The Mediating Role of Corporate Green Image in The Effect of Green Value on \\ Repurchase: A Research on Airway Passengers
}

DOI: https://doi.org/10.25204/iktisad.842156

Ahmet ÇETİNDAŞ ${ }^{* *}$
Gülendam SEVINÇ KAYA $^{* * *}$

Makale Bilgileri

Makale Türü:

Araştırma Makalesi

Geliş Tarihi:

17.12.2020

Kabul Tarihi:

22.02.2021

(C) 2021 IKTTISAD

Tüm haklarl

saklidir.

\begin{abstract}
$\ddot{O} z$
Bu çalı̧̧mada havayolu yolcu taşımacıllğında çevreci değerin kurumsal çevreci imaj ve tekrar satın alma üzerindeki etkisi araştırılmıştır. Ayrıca kurumsal çevreci imajın tekrar satın almaya doğrudan ve dolayl etkileri incelenmistir. Bu amaçla Gaziantep havalimanından seyahat eden 465 yolcudan anket yoluyla veri toplanmıs ve SPSS Process Macro yöntemiyle analiz edilmiştir. Analiz sonucunda çevreci değerin kurumsal çevreci imaj ve tekrar satın almayı pozitif yönde etkilediği bulunmuştur. Böylelikle yüksek çevreci değer algllayan yolcuların daha yüksek kurumsal çevreci imaj algılayacağ̀ ve tekrar satın almaya daha eğilimli olacakları ispatlanmışstır. Ayrıca kurumsal çevreci imajın tekrar satın almayı pozitif yönde anlamlı olarak etkilemiş olması çevreci yaklaşımlar açısından tatmin olan yolcuların bu deneyimi tekrar yaşamak isteyebileceklerini gösterilmiştir.
\end{abstract}

Anahtar Kelimeler: Çevreci değer, tekrar satın alma, kurumsal çevreci imaj, çevreci havayolu.

$\underline{\text { Article Info }}$

Paper Type:

Research Paper

Received:

17.12.2020

Accepted:

22.02.2021

(C) 2021 JEBUPOR All rights reserved.

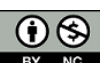

\begin{abstract}
In this study, the effect of environmental value on corporate environmental image and repurchase in airline passenger transportation was investigated. In addition, the direct and indirect effects of corporate environmental image on repurchase were examined. For this purpose, data was collected through a questionnaire from 465 passengers traveling from Gaziantep airport and analysed with the SPSS Process Macro method. The result of the analysis showed that environmental value positively affects corporate environmental image and repurchase. Thus, it has been proven that passengers who perceive high environmental value will perceive a higher corporate environmental image and will be more inclined to repurchase. In addition, since the corporate environmental image has positively affected repurchase, it was shown that passengers who are satisfied in terms of environmentalist approaches may want to experience this experience again.
\end{abstract}

Keywords: Green value, repurchase, corporate green image, green airline.

Atıf/ to Cite (APA): Çetindaș, A. \& Sevinç Kaya, G. (2021). Çevreci Değerin Tekrar Satın Alma Üzerine Etkisinde Kurumsal Çevreci İmajın Aracı Rolü: Havayolu Yolcuları Üzerine Bir Araştırma. Íktisadi İdari ve Siyasal Araştırmalar Dergisi, 6(14), 142-155.

\footnotetext{
${ }^{*}$ Bu makale, Hasan Kalyoncu Üniversitesi, Sosyal Bilimler Enstitüsü, Uluslararası Ticaret ve Lojistik Anabilim Dalı’nda 16.01.2020 tarihinde tamamlanan "Havayolu Yolcu Taşımacılığında Çevreci Yaklaşımların Deneyimsel Tatmin ve Tekrar Satın Alma Niyeti Üzerinde Etkisi” başlıklı yüksek lisans tezinden türetilmiştir.

**ORCiD Dr. Öğretim Üyesi, Hasan Kalyoncu Üniversitesi, İISBF, Uluslararası Ticaret ve Lojistik Bölümü, ahmet.cetindas@hku.edu.tr ***ORCID Büro ve Gişe Yetkilisi, PTT, gulendamsevincc@gmail.com
} 


\section{Extended Abstract}

\section{Background:}

Air transport plays a critical role in the global economy by ensuring the movement of people and goods between countries. With the rapid growth in demand, emissions from air transport are increasing despite the decrease in emissions from other modes of transport. In addition, it is seen that efforts made to decrease noise, in general, are reduced. Environmental commitments of Airline firms play an important role in creating a green-conscious airline image. For this reason, it is very important to determine the measures that are perceived as effective in reducing the environmental impacts of airline transportation, in which the airlines can include their corporate image. It will be a very important advantage for airline companies to focus on their green identities and create an environmentally friendly image that can be attractive to consumers since the image is used by consumers to separate companies from each other and triggers repurchases.

\section{Research Purpose:}

The main purpose of this study is to examine the impact of green value and corporate green image on the repurchase of Airline passengers and the mediating role of corporate green image in this effect. The impact of green value on corporate green image is also analysed.

\section{Methodology:}

The research was carried out on passengers using Gaziantep airport where 465 surveys were applied. Exploratory and confirmatory factor analyses were performed for each scale used in the study, and correlation analysis was conducted to understand the relationships between variables. The Process macro method developed by Hayes (2018) was used to test the hypotheses. The most important feature of this method that distinguishes it from others is that it can simultaneously test the mediation effect as well as the direct effects. As a result, the findings obtained from the analysis were compared with the literature and suggestions were made to the managers and researchers.

\section{Findings:}

It was proved that there is an impact of green value and corporate green image on repurchase. Also, that corporate green image plays a mediating role in this relation.

\section{Conclusions:}

As it is expected, it is understood that companies with green values in the presence of passengers show a higher corporate green image. It is an important finding that airline companies that create green value can reflect this on their image. In addition, the fact that green value has affected repurchase means that today's passengers attach importance to green values, have ecological concerns, and therefore may tend to repurchase. Furthermore, it has been understood that today's conscious passengers have a higher repurchase tendency towards environmentally friendly companies which are able to meet green demands. It was also found that an important part of the effect of green value on repurchase in airline companies is mediated by corporate green image. 


\section{GíRiş}

Havayolu taşımacılığı insanların ve malların ülkeler arası dolaşımını sağlayarak küresel ekonomide kritik bir rol oynamaktadır. Talepteki güçlü büyüme ile havayolu taşımacılığından kaynaklanan emisyonlar, başka ulaşım türlerinden kaynaklanan emisyonlardaki azalmaya karşın, artmaktadır. Ayrıca, genel anlamda gürültü azaltmak için yapılan uğraşların da azaldığı görülmektedir. Milyonlarca insan havayollarının bu zararlarından etkilenmektedir. Sonuç olarak artan bu hareketlilik ulusların ekonomik güç ve güvenlikleri açısından artan bir çevresel kalite sorunu oluşturmaktadır (Waitz vd, 2004: 3).

Havayollarının çevresel taahhütlerinin algılanması çevreye duyarlı havayolu görüntüsünün oluşturulmasında önemli bir rol oynamaktadır. Bu nedenle, havayolu taşımacılığının çevresel etkilerini azaltmada etkili olarak algılanan, havayollarının kendi kurumsal imajını da dâhil edilebileceği önlemleri belirlemesi oldukça önemlidir. Havayolları müşterilere verdiği çevresel taahhütleri göstermek amaçlı belli pazarlama mesajları kullanmaktadır. Bazı havayolu işletmeleri (örneğin, Flybe ve Easyjet) web sitelerinde konuya daha fazla odaklanırken, diğerleri (örneğin, Wizz Air, BmiBaby) bu konuyu internet ortamında ele almamaktadır. Ancak hava yolu işletmelerinin ekolojik sorunlara daha yeni uçakların kullanımı ve yer hizmetlerinde elektrikli araçların kullanımı gibi bazı ortak önlemler aldığı görülmektedir (Mayer vd., 2012: 4).

Çevre duyarlılığına sahip işletmeler, minimum çevre zararlılığına sahip, ortaya çıkardıkları zararları yok etmek için çözüm arayan, ortaklarını çevre duyarlılığına sahip işletmelerden seçen ve en önemlisi çevreci olmayı sadece pazarlama stratejisi olarak görmeyen, bunu bir kalite ve anlayış haline getirip yaygınlaştırmaya çalışan işletmelerdir (Emgin \& Türk, 2004).

Tüketiciler çevresel etkilerin farkında olmasına ve bunları bir dereceye kadar ele almaya istekli olmalarına rağmen, seyahat etme istekleri ve yaşam tarzlarının bu kısmından vazgeçmek istememektedirler. $\mathrm{Bu}$ durumda, havayollarının pazarlama yönünü çevresel kimlik bilgilerine odaklaması ve bu yönüyle tüketiciler için çekici olabilecek çevreci bir imaj yaratması kendileri için oldukça önemli bir avantaj olacaktır. Çünkü imaj, tüketiciler tarafından şirketleri birbirinden ayırmak için kullanılmakta (Mayer vd, 2012: 2) ve tekrar satın almayı tetiklemektedir.

\section{LITERATÜR TARAMASI VE ARASTTIRMA HIPOTEZLERININ KURULMASI}

\section{1. Çevreci Değer ve Kurumsal Çevreci İmaj İlişkisi}

Çevreci değer, sosyal değer bilinci ile doğru orantılı olarak artmaktadır. Bu sebeple çevre dostu ürün ve hizmet sunan firmalar ekolojik problemlerden endişe duymadan yeni pazarlara girip etkinliklerini arttırır ve ekonomik avantaj sahibi olurlar. İşletmelerde çevreci değer, oluşturduğu çevreci imaj sebebiyle, çevreye duyarlı insanlar için en önemli seçim sağlayıcı olarak ele alınmaktadır. Bakıldığında eğer bir ürün sosyal çevreden kabul görmüyor ve onay almıyorsa memnuniyetsizlik yaratmakta ve tercih edilmemektedir (Doszhanov \& Ahmad, 2015: 4).

Yadav vd. (2016) otellerde çevreci faaliyetlerin ve çevreci imajın kurumsal imaj üzerindeki etkisini araştırmıştır. Bulgular, çevreci faaliyetlerin ve çevreci imajın kurumsal imajı önemli ölçüde etkilediğini ve bunun tüketicinin oteli ziyaret etme niyetinde önemli bir etkiye yol açtığını göstermektedir. Benzer şekilde Villanueva-Ponce vd. (2015) çevreci değer ve çevreci ürün tasarımının kurumsal imaj üzerinde pozitif etkisi olduğunu tespit etmiştir. Yine Widyastuti vd. (2019) Unilever müşterileri üzerinde yaptığı araştırmada çevreci pazarlama uygulamalarının işletmelerin çevreci imajına pozitif değer kattığı sonucuna ulaşmıştır.

Önceki çalışmalar göz önüne alındığında birinci hipotez aşağıdaki şekilde kurulmuştur:

H1: Havayolu yolcu taşımacılığında çevreci değerin kurumsal çevreci imaj üzerine pozitif yönde anlamlı etkisi vardır. 


\section{2. Çevreci Değer ve Tekrar Satın Alma İlişkisi}

Çevreci olmak bir şirketin kimliğindeki değişikliktir ve şirketin çevreci olarak algılanabilmesi için müşterilere ve diğer paydaşlara bu değişikliğin geçirilmesi gerekmektedir (Biloslavo \& Trnavcevic, 2009: 1165). Tekrar satın alma niyeti ise, bireylerin mevcut durumu ve muhtemel koşulları göz önünde bulundurarak, aynı işletmeden belirlenmiş bir hizmeti yeniden satın alma konusundaki kararı olarak tanımlanmaktadır (Hellier vd., 2003: 4).

Son on yılda, tüketicilerin çevreye ve ekolojik tüketici davranışlarına yönelik tutumları üzerine araştırmalar artmıştır. Farklı pazarlardaki tüketiciler satın alma davranışlarını çevre dostu ürünler lehine değiştirmiş ve şirketler bu eğilime çevresel ihtiyaçları ele alarak cevap vermiştir (Finisterra do Paço vd., 2009: 19)

Ariffin vd. (2016)'nin Malezya'da çevreye duyarlı ürünler ve tekrar satın alma niyetine yönelik yaptığı araştırmada çevreci değerin hem algılanan kalite hem de tekrar satın alım niyeti üzerinde pozitif bir etkiye sahip olduğunu ispatlamıştır. Çalışma, tüketicilerin çevreye duyarlı ürünlerin kalite değişikliklerini daha iyi algılayacakları ve bunun da kalite tanımlamalarını güçlendirdiği ve daha fazla tekrar satın alım niyetine yol açtığını göstermektedir. Araştırma sonuçları çevreye duyarlı ürünlerin tüketicilerde tekrar satın alma niyeti oluşturduğunu açıklıkla göstermektedir. Tüketiciler çevre dostu ürünlere ve bu ürünlerin özelliklerine çok daha fazla ilgi duyup bunları satın almaya yönelmektedir. Sonuç olarak üreticiler veya hizmet sağlayıcıları tüketicilerin dikkatini çekmek ve tekrar satın alımlarını teşvik etmek amaçlı çevreci ürünleri hakkında daha fazla bilgi vermeyi tercih etmektedirler.

Lam vd. (2016: 55) yapmış olduğu araştırmada çevreci algılanan değer ile tekrar satın alma davranışı arasında pozitif bir ilişki olduğunu göstermiştir. $\mathrm{Bu}$ bulgu, firmaların pazarlama faaliyetlerinin çevreci tutumlarını ön plana çıkardığ 1 müddetçe tekrar satın alma davranışının gerçekleşeceği şekilde yorumlanmıştır. Niu vd. (2016) Tayvan'da havayollarının çevre koruma politikalarına yolcu perspektifinden bakan bir araştırma yapmış ve yolcuların çevre koruma faaliyetlerini destekleyen havayollarını seçmeyi tercih ettiklerini göstermiştir. Yıldız ve Çiğdem (2018) ise algılanan değerin havayolu yolcularının memnuniyetini arttırdığını bulmuştur.

$\mathrm{Bu}$ çalışmalardan yola çıkarak havayolu yolcu taşımacılığında çevreci değerin tekrar satın almayı beraberinde getireceği iddiası ile ikinci hipotez aşağıdaki şekilde oluşturulmuştur.

H2: Havayolu yolcu taşımacılığında çevreci değerin tekrar satın alma üzerine pozitif yönde anlamlı etkisi vardır.

\subsection{Kurumsal Çevreci İmaj ve Tekrar Satın Alma İlişkisi}

Kurumsal çevreci imaj, çevreyi önemseyen ve çevresel kaygıları olan bir markanın tüketicilerin zihnindeki algısıdır (Chen, 2010: 310). Bravo vd. (2009) kurumsal imajı bellekte saklanan birikmiş duygular, fikirler, tutumlar ve tecrübeler sonucu müşterilerin zihninde oluşan genel izlenim olarak tanımlarken, bu izlenimin pozitif-negatif anlamlara dönüşüp firma adını akıllara getirmesi şeklinde tanımlamaktadır. Chen (2008) ise kurumsal çevreci imajı, firmanın ve personelin müşteriler ve toplum ile olan ilişkisinin çevresel taahhütler ve endişeler ile bağlantılı olması şeklinde tanımlamaktadır. Kurumsal çevreci imaj, genel anlamda sahip olunan kurumsal imajın bir alt kümesi olarak kabul edilmektedir. Bir firma çevre dostu ürün ve hizmet sunmaya başladığında, tüketici aklındaki mevcut kalite algılarını daha çevreci bir marka imajına dönüştürecektir (Doszhanov \& Ahmad, 2015: 3).

Hagmann vd. (2015) hava taşımacılığında çevreci imajın yolcu algısını ve tercihlerini ne yönde etkilediğini araştırmıştır. Çalışma sonuçları göstermektedir ki; havayollarının çevreci imajları yolcuların rezervasyon seçimlerine pozitif etki etmektedir ve yolcular çevreci bir imaj için daha fazla 
para ödemeyi göze almaktadır. Ayrıca Wu vd. (2018) çevreci kurumsal imaj ile tatminin pozitif yönlü ilişki içerisinde olduğunu göstermiştir.

Havayolu yolcu taşımacılığında kurumsal çevreci imajın tekrar satın almayı etkileyeceği düşüncesiyle çalışmanın üçüncü hipotez aşağıdaki gibi kurulmuştur:

H3: Havayolu yolcu taşımacılığında kurumsal çevreci imajın tekrar satın alma üzerinde pozitif yönde anlamlı etkisi vardır.

\section{4. Çevreci Değerin Tekrar Satın Alma Üzerindeki Etkisinde Kurumsal Çevreci İmajın Araci Rolü}

Önceki çalışmalar incelendiğinde kurumsal çevreci imajın aracılık rolüyle ilgili çalışmaların sınırlı olduğu görülmektedir. Ancak kurumsal çevreci imajın bir üst başlığı olan kurumsal imajın aracılığını test eden çalışmalar mevcuttur. Genel olarak kurumsal imajın aracılık rolü hizmet kalitesi konulu çalışmalarda incelenmiştir.

Hassan vd. (2019) yaptığı çalışmada teknik okullardaki hizmet kalitesi ile öğrenci sadakati arasındaki ilişkide kurumsal imajın aracı rolünü araştırmış ve hizmet kalitesinin sadakat üzerindeki etkisinde kurumsal imajın kısmi aracılık ettiğini bulmuştur. Benzer şekilde Sadiartha \& Darmiyanti (2019)'da Endonezya perakende sektörü üzerinde yaptığı araştırmada hizmet kalitesinin satın alma kararı üzerindeki etkisinde kurumsal imajın aracı rolünü bulgulamıştır. Cheng \& Abdul (2013) Malezya hotelleri üzerinde yaptığ 1 araştırmada kurumsal imajın müşteri memnuniyeti ile müşteri sadakati arasındaki ilişkiye aracılık ettiğini göstermiştir.

Böylelikle çalışmanın sonuncu hipotezi şu şekilde oluşturulmuştur:

H4: Havayolu yolcu taşımacılığında çevreci değerin tekrar satın alma üzerindeki etkisinde kurumsal çevreci imajın aracı rolü bulunmaktadır.

\section{ARAŞTIRMANIN YÖNTEMI VE BULGULAR}

Çalışmanın tasarımı nicel araştırma tekniklerinin kullanımına uygunluk göstermektedir. Çalışmada kullanılan ölçeklerin literatürde hazır olarak bulunması ve nicel araştırmaların olayları ölçülebilir şekilde ortaya koyması bu yöntemin seçilmesinin başlıca sebeplerindendir. Çalışmada kullanılan her bir ölçek için keşfedici ve doğrulayıcı faktör analizi yapılmış ve değişkenler arasındaki ilişkileri anlamak için korelasyon analizi yapılmıştır. Hipotezlerin testi için Hayes (2018) tarafından geliştirilen Process makro yöntemi kullanılmıştır. Bu yöntemi diğer yöntemlerden ayıran en önemli özelliği aynı anda direkt etkilerle birlikte aracılık etkisini de test edebilmesidir. Analizler sonucunda ortaya çıkan bulgular, literatürle karşılaştırılıp yönetici ve araştırmacılara önerilerde bulunulmuştur. Kuramdan ve önceki araştırmalardan yola çıkılarak oluşturulan araştırma modeli Şekil 1'de gösterilmiştir.

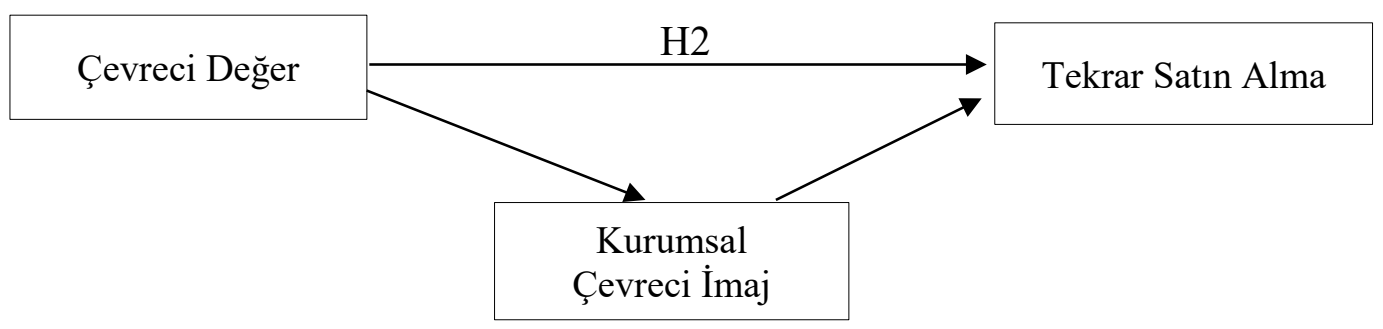

H4: Kurumsal çevreci imajın aracı etkisi

Sekil 1: Araştırma Modeli 


\subsection{Araştırmanın Örneklemi ve Demografik Bulgular}

Araştırmanın evreni olarak Gaziantep'ten uçan havayolu yolcuları seçilmiştir. 2018 yılında toplam 2,65 milyon yolcuya ev sahipliği yapan Gaziantep havalimanı Türkiye'de faaliyet gösteren en yoğun onuncu havalimanıdır (DHMİ, 2019). Araştırmanın örneklemini ana kütle içerisinden kolayda örnekleme yöntemi ile seçilen 465 yolcu oluşturmaktadır. Anketlerin bir kısmı çevrimiçi olarak toplanmış bir kısmı ise Gaziantep havalimanında uçuş bekleyen yolculardan elden toplanmıştır. Katılımcılara anket formunu doldurmaya başlamadan önce çevrecilik faaliyetleri ile ilgili ön bilgilendirme yapılmıştır.

Araştırmaya katılan yolcuların cinsiyetlerine ilişkin bulgular Tablo 1'de verilmiştir.

Tablo 1: Cinsiyet Frekans Dağılımı

\begin{tabular}{|l|c|c|}
\hline Cinsiyet & Frekans & Yüzde \\
\hline Erkek & 332 & 71,4 \\
\hline Kadın & 133 & 28,6 \\
\hline Toplam & 465 & 100 \\
\hline
\end{tabular}

Çalışmaya katılım gösteren yolcularının cinsiyet dağılımlarına bakıldığında; \%71,4'ünün erkek, \%28,6'sinin ise kadın katılımcılardan oluştuğu görülmektedir. Araştırmaya katılan yolcuların yaşlarına ilişsin bulgular Tablo 2'de verilmiştir.

Tablo 2: Yaş Frekans Dağılımı

\begin{tabular}{|l|c|c|}
\hline Yaş & Frekans & Yüzde \\
\hline $18-24$ & 128 & 27,5 \\
\hline $25-34$ & 204 & 43,8 \\
\hline 35 ve üzeri & 133 & 28,7 \\
\hline Toplam & 465 & 100 \\
\hline
\end{tabular}

Katılımcıların yaşlarına ilişkin dağılıma bakıldığında yolcuların \%43,8'nin 25- 34 yaş ve \%27,5'inin 18-24 yaş aralığında oldukları görülmektedir. Katılımcıların geri kalan \%28,7'lik kısmının ise 35 yaş ve üzeri grupta yer aldıkları ortaya çıkmıştır. Araştırmaya katılan yolcuların eğitimlerine ilişkin bulgular Tablo 3'de verilmiştir.

Tablo 3: Eğitim Frekans Dağılımı

\begin{tabular}{|l|c|c|}
\hline Ĕ̆itim & Frekans & Yüzde \\
\hline Lise & 104 & 22,3 \\
\hline Lisans & 202 & 43,5 \\
\hline Ön Lisans & 84 & 18 \\
\hline Lisansüstü & 75 & 16,2 \\
\hline Toplam & 465 & 100 \\
\hline
\end{tabular}

Katılımcıların eğitimlerine ilişkin dağılım incelendiğinde; \%43,5'inin lisans, \%22,3'ünün lise, \%18'inin ön lisans ve \%16,2'sinin lisansüstü eğitim düzeylerinde yer aldıkları görülmektedir. Araştırmaya katılan yolcuların gelirlerine ilişkin bulgular Tablo 4'de verilmiştir. 
Tablo 4: Gelir Frekans Dağılımı

\begin{tabular}{|l|c|c|}
\hline Gelir & Frekans & Yüzde \\
\hline $1000-3000 \mathrm{TL}$ & 73 & 15,7 \\
\hline $3001-6000 \mathrm{TL}$ & 183 & 39,4 \\
\hline $6001-9000 \mathrm{TL}$ & 107 & 23 \\
\hline 9001 TL ve üzeri & 102 & 21,9 \\
\hline Toplam & 465 & 100 \\
\hline
\end{tabular}

Çalışmaya katılım gösteren havayolu yolcularının gelirlerine ilişkin dağılım incelendiğinde; \%39,4'ünün 3001-6000 TL arası gelire sahip oldukları, \%23'ünün 6001-9000 TL arası gelire sahip oldukları ve \%21,9'unun ise 9001 TL ve üzeri gelir grubunda yer aldıkları görülmektedir. Katılımcıların \%15,7'lik kısmının gelir aralığının ise 1000-3000 TL arasında olduğu gözlemlenmiştir. Araştırmaya katılan yolcuların medeni durumuna ilişkin bulgular Tablo 5'de verilmiştir.

Tablo 5: Medeni Durum Frekans Dağılımı

\begin{tabular}{|l|c|c|}
\hline Medeni Durum & Frekans & Yüzde \\
\hline Evli & 237 & 50,9 \\
\hline Bekar & 228 & 49,1 \\
\hline Toplam & 465 & 100 \\
\hline
\end{tabular}

Anket çalışmasına katılım sağlayan bireylerin medeni durumlarına ilişkin dağılım incelendiğinde; \%50,9'unun evli ve \%49,1'inin bekar olduğu bulgulanmıştır. Araştırmaya katılan yolcuların iş durumuna ilişkin bulgular Tablo 6' de verilmiştir.

Tablo 6: İş Durumu Frekans Dağılımı

\begin{tabular}{|l|c|c|}
\hline Meslek & Frekans & Yüzde \\
\hline İşveren & 42 & 9 \\
\hline Serbest & 51 & 10,9 \\
\hline Özel Sektör Çalışanı & 173 & 37,2 \\
\hline Devlet Memuru & 88 & 18,9 \\
\hline Ev Hanımı & 21 & 4,5 \\
\hline Öğrenci & 50 & 10,8 \\
\hline Emekli & 21 & 4,5 \\
\hline İşsiz & 19 & 4,2 \\
\hline TOPLAM & 465 & 100 \\
\hline
\end{tabular}

Çalışmaya katılım gösteren bireylerin meslek dağılımları incelendiğinde; \%37,2'sinin özel ve \%18,9'unun kamu sektöründe çalışan olarak kendilerini tanımladıkları, \%10,9'unun serbest çalışan ve \%10,8'inin ise öğrenci olduğu gözlemlenmektedir. Katılımcıların kalanlardan \%9'unu işveren, \%4,5'inin emekli, \%4,5'inin ev hanımı ve \%4,2'sinin işsiz olduğu anlaşılmıştır. Araştırmaya katılan yolcuların çevreci havayolu için ödemeye razı olduğu fazladan ödemeye ilişkin bulgular Tablo 7'de verilmiştir. 
Tablo 7: Çevreci Havayolu İçin Ek Ödeme Frekans Dağılımı

\begin{tabular}{|l|c|c|}
\hline $\begin{array}{l}\text { Çevreci havayolu } \\
\text { için ek ödeme }\end{array}$ & Frekans & Yüzde \\
\hline$\% 10-\% 20$ arası & 210 & 45,2 \\
\hline$\% 21-\% 30$ arası & 57 & 12,3 \\
\hline$\% 31-\% 40$ arası & 72 & 15,6 \\
\hline$\% 41-\% 50$ aras1 & 38 & 8,1 \\
\hline$\% 51$ ve üzeri & 30 & 6,4 \\
\hline Fazla ödeme yapmam & 58 & 12,4 \\
\hline TOPLAM & 465 & 100 \\
\hline
\end{tabular}

Katılımcılardan \%12,4'ünün fazla ödeme yapmamayı tercih edeceğini belirtirken; $\% 45,2$ 'lik k1sm1 \%10-20 aras1, \%15,6's1 \%31-40 aras1, \%8, '’ i ise \%41-50 aras1 fazla ödeme yapabileceklerini belirtmiştir. Çevreci bir havayolu için \%51 ve üzeri daha fazla ödeme yapabileceğini ifade eden katılımcıların oranı ise sadece $\% 6,4$ olarak tespit edilmiştir. Araştırmaya katılan yolcuların uçuş sıklığına ilişkin bulgular Tablo 8'de verilmiştir.

Tablo 8: Uçuş Sıklığı Frekans Dağılımı

\begin{tabular}{|l|c|c|}
\hline Uçuş sıklı̆̆ & Frekans & Yüzde \\
\hline Ayda Bir Defa & 75 & 16,1 \\
\hline Ayda İki Defa & 35 & 7,5 \\
\hline Ayda İki Defadan Fazla & 48 & 10,3 \\
\hline Yılda İki Defadan Fazla & 240 & 51,7 \\
\hline Yılda İki Defa & 44 & 9,5 \\
\hline Diğer & 23 & 4,9 \\
\hline TOPLAM & 465 & 100 \\
\hline
\end{tabular}

Anket uygulamasına katılımın ön şartı olan havayolu taşımacılığını seyahatlerinde en az bir defa kullanmış olma şartını taşıyan katılımcıların havayollarını kullanım sıklıkları incelendiğinde; \%51,7'sinin yılda iki defadan fazla, \%9,5'inin y1lda iki defa, \%16,1'inin ayda bir defa, \%7,5'inin ayda iki defa ve \%10,3'ünün ayda iki defadan fazla havayolu ile seyahat ettikleri gözlemlenmiştir. Araştırmaya katılan yolcuların tercih ettikleri firmaya ilişkin bulgular Tablo 9'da verilmiştir.

Tablo 9: Tercih Edilen Firma Frekans Dağılımı

\begin{tabular}{|l|c|c|}
\hline Firma Tercihi & Frekans & Yüzde \\
\hline Türk Hava Yolları & 217 & 46,6 \\
\hline Pegasus & 96 & 20,6 \\
\hline Anadolu Jet & 115 & 24,7 \\
\hline Atlas Global & 19 & 4,2 \\
\hline Sun Express & 18 & 3,9 \\
\hline TOPLAM & 465 & 100 \\
\hline
\end{tabular}

Anket formunda yer alan demografik sorulardan sonuncusu olan ve çalışmada yer alan diğer ölçek sorularının cevaplanmasında temel olarak ele alınan "En sık tercih ettiğiniz havayolu firması hangisidir?” sorusuna katılımcıların verdiği yanıtlar şu şekildedir; \%46,6 Türk Hava Yolları, \%24,7 Anadolujet, \%20,6 Pegasus, \%4,2 Atlas Global, \%3,9 Sun Express. 


\subsection{Araştırmanın Ölçekleri}

Araştırmada kullanılan çevreci değer ve kurumsal çevreci imaj ölçeği Wu vd. (2018)'in çalışmasından, tekrar satın alma ölçeği ise Ruiz vd. (2008)'in çalışmasından alınmıştır. Çevreci değer ölçeği Wu vd. (2018)'in çalışmasında bulunun algılanan çevreci değer ve kurumsal çevreci itibar ölçeklerinin birleşiminden oluşmaktadır. Bu iki ölçek çalışılan örneklemde tek faktörlü bir yapıda geçerlenmiştir. Ölçeklerin soruları incelendiğinde her ikisinde de firmanın çevreci yaklaşımları ve değerleriyle ilgili maddelerden oluştuğu görülmüş ve bu sebeple her iki değişkene ait 3'er ifade birleşerek 6 maddeli bir çevreci değer ölçeği uyarlanmıştır. Ölçek maddeleri alınan kaynaklarda İngilizce olarak sorulduğundan 3 akademisyen yardımıyla çeviri- tekrar çeviri yöntemi ile Türkçeye çevrilmiştir. Katılımcılara sorular 5'li likert ölçeği şeklinde sorulmuştur. Likert ölçekli sorular katılma derecesini göstermektedir.

\section{3. Ölçeklerin Güvenilirliği, Yapı Geçerliği ve Yakınsak Geçerliliği}

Öncelikle araştırmanın ölçeklerinin güvenirliğini test etmek için güvenirlik analizi, yapı geçerliğini sağlamak için keşfedici faktör analizi (KFA) ve yapılmış ve doğrulayıcı faktör analizi (DFA) yapılmıştır.

Çevreci değer ölçeği için KFA ve güvenilirlik analizi sonuçları Tablo 10'ds verilmiştir.

Tablo 10: Çevreci Değer Faktör Yükleri ve Güvenilirlik Analizi

\begin{tabular}{|l|c|}
\hline Maddeler & Faktör Yükü \\
\hline KCIT3: Bu havayolunun çevreci imajı ve itibarı çok iyi hatta diğer havayollarından daha iyidir &, 864 \\
\hline ACD3: Bu havayolunu kullanıyorum çünkü diğer havayollarına göre çevre ile daha çok ilgileniyor &, 790 \\
\hline ACD2: Bu havayolu şirketinin çevresel performansı beklentilerimi karşıllyor &, 773 \\
\hline KCIT1: Bu çevreci havayolu bana güven aşılamaktadır &, 759 \\
\hline KCIT2: Bu havayolu arkadaşlarım ve ailem içinde çevre dostu imaja sahiptir &, 750 \\
\hline ACD1: Bu havayolu şirketinin çevresel fonksiyonları benim için çok iyi bir değer sağlıyor &, 648 \\
\hline Cronbach's Alfa: ,854 KMO: ,771 Toplam Açılanan Varyans: \%58,76 & \\
\hline
\end{tabular}

KFA sonucu çevreci değer ölçeğinin faktör yükleri 0,648 ile 0,864 aralığında elde edilmiştir. Wu vd. (2018)'in geliştirdiği Algılanan Çevreci Değer ve Kurumsal Çevreci İtibar ölçekleri çalışılan örneklemde tek faktör olarak geçerlenmiştir. Ölçeklerin soruları incelendiğinde her ikisinde de firmanın çevreci yaklaşımları ve değerleriyle ilgili maddelerden oluştuğu görülmüştür. Bu sebeple her iki değişkene ait 3'er ifade birleşerek 6 maddeli bir çevreci değer ölçeği uyarlanmıştır. Ölçeğin toplam varyansın \%58,76'ini açıkladığı tespit edilmiştir. Güvenilirlik analizi sonucu elde edilen alfa katsayısı 0,854 olarak bulunmuştur. Bu bulgu ölçeğin güvenilir olduğunu göstermektedir.

Kurumsal çevreci imaj ölçeğinin KFA ve güvenilirlik analizi sonuçları Tablo 11'de verilmiştir.

Tablo 11: Kurumsal Çevreci İmaj Faktör Yükleri ve Güvenilirlik Analizi

\begin{tabular}{|l|c|}
\hline Maddeler & Faktör Yükü \\
\hline KCIM3: Bu havayolundaki çevre dostu ürün ve hizmetler güvenilir ve istikrarlıdır. &, 895 \\
\hline KCIM2: Bu havayolu, çevresel özelliklerinden dolayı benim için değer teşkil etmektedir. &, 887 \\
\hline KCIM1: Bu havayolunu kullanıyorum çünkü çevre dostudur. &, 882 \\
\hline KCIM6: Bu havayolu çevre yönetimi ve yeşil yenilik açısından mükemmel performansa sahiptir. &, 770 \\
\hline KCIM5: Bu havayolu müşterilerin gözünde iyi bir çevreci intibaa ya sahiptir. &, 749 \\
\hline KCIM4: Bu havayolu yolcuların çevreci taleplerini karşllayabilecek yetiye sahiptir. &, 703 \\
\hline Cronbach's Alfa: ,899 KMO: ,7850 Toplam Açıklanan Varyans: \%66,87 & \\
\hline
\end{tabular}


KFA sonucu Kurumsal çevreci imaj ölçeğinin faktör yükleri 0,703 ile 0,895 aralığında elde edilmiştir. KMO değeri 0,7850 olarak bulunmuş ve $p<0,01$ olarak elde edilmiştir. Böylelikle örneklem büyüklüğünün faktör analizi için uygun olduğu anlaşılmıştır. Ölçeğin toplam varyansın \%66,87'sini açıkladığı ve güvenilirlik analizi sonucu alfa katsayısının 0,899 olduğu tespit edilmiştir. Ölçeğin güvenilir olduğu anlaşılmıştır.

Tekrar satın alma ölçeğinin KFA ve güvenilirlik analizi sonuçları Tablo 12'de verilmiştir.

Tablo 12: Tekrar Satın Alma Faktör Yükleri ve Güvenilirlik Analizi

\begin{tabular}{|l|c|}
\hline Maddeler & Faktör Yükü \\
\hline $\begin{array}{l}\text { TSN1: Mevcut hizmet devam ettiği sürece tercih ettiğim havayolu firmasını değiştirmeyi } \\
\text { düşunmüyorum. }\end{array}$ &, 935 \\
\hline TSN2: Önümüzdeki dönemlerde tercih ettiğim havayolu firması ile seyahat etme niyetindeyim &, 904 \\
\hline TSN3: Tercih ettiğim havayolu firmasını ciddi olarak değiştirmeyi düşünmüyorum. &, 805 \\
\hline TSN4: İhtiyaç duymam halinde yine bu havayolu firmasını tercih ederim. &, 498 \\
\hline Cronbach's Alfa: ,809 KMO: 0,695 Toplam Açklanan Varyans: \%64,70 & \\
\hline
\end{tabular}

KFA sonucu tekrar satın alma ölçeğinin faktör yükleri 0,498 ile 0,935 aralığında elde edilmiştir. KMO değeri 0,695 olarak bulunmuştur ve $p<0,01$ olarak elde edilmiștir. Böylelikle örneklem büyüklüğünün faktör analizi için uygun olduğu anlaşılmıştır. Ölçeğin toplam varyansın \%64,70 ’ini açıkladığı ve güvenilirlik analizi sonucu alfa katsayısının 0,809 olduğu tespit edilmiştir. Ölçeğin güvenilir olduğu anlaşılmıştır.

Yakınsak Geçerliliği sonucu AVE değerlerinin hepsi 0,5'ten büyük ve CR değerlerinin hepsi 0,7'den büyük bulunmuştur. CR>AVE şartı da sağlanmıştır (Fornell ve Larcker, 1981). Yakınsak geçerliliği sonucu ölçeklerin AVE ve CR değerleri Tablo 13'de gösterilmiştir.

Tablo 13: Yakınsak Geçerliliği (AVE ve CR)

\begin{tabular}{|l|c|c|}
\hline Değişken & AVE & CR \\
\hline Çevreci Değer & 0,58 & 0,89 \\
\hline Kurumsal Çevreci İmaj & 0,66 & 0,92 \\
\hline Tekrar Satın Alma & 0,64 & 0,87 \\
\hline
\end{tabular}

KFA, yakınsak geçerliliği ve güvenilirlik analizinden sonra ölçeklerin yapı geçerliliğini test etmek için DFA yapılmıştır. DFA sonucu ölçeklerin sağladığı uyum iyiliği değerleri Tablo 14'de verilmiştir.

Tablo 14: DFA Uyum İyiliği Değerleri

\begin{tabular}{|l|c|c|c|c|c|c|c|c|}
\hline Değişken & CMIN & CMIN/DF & GFI & CFI & TLI & NFI & AGFI & RMESA \\
\hline Çevreci Değer & 9,298 & 2,324 & 0,993 & 0,996 & 0,985 & 0,993 & 0,966 & 0,053 \\
\hline Kurumsal Çevreci İmaj & 10,428 & 3,476 & 0,993 & 0,996 & 0,982 & 0,995 & 0,949 & 0,073 \\
\hline Tekrar Satın Alma & 2,447 & 2,447 & 0,997 & 0,998 & 0,991 & 0,997 & 0,974 & 0,056 \\
\hline
\end{tabular}

DFA sonucu ölçeklerin uyum iyilik değerlerinin kabul edilebilir düzeyde olduğu anlaşılmıştır (Bayram, 2013; Civelek, 2018). Ayrıca DFA sonucu çevreci değer ölçeğinin faktör yükleri 0,526 ile 0,903 arasında, kurumsal çevreci imaj ölçeğinin faktör yükleri 0,614 ile 0,900 arasında ve tekrar satın alma ölçeğinin faktör yükleri 0,564 ile 0,947 arasında bulunmuştur.

Değişkenler arasındaki ilişkiyi görebilmek için korelasyon analizi yapılmıştır. Korelasyon analizine ilişkin bulgular Tablo 15'de verilmiştir. 
Tablo 15: Korelasyon Analizi

\begin{tabular}{|l|c|c|c|c|c|}
\hline & Ortalama & Std. Sapma & Çevreci Değer & $\begin{array}{c}\text { Kurumsal Çevreci } \\
\text { İmaj }\end{array}$ & Tekrar Satın Alma \\
\hline Çevreci Değer & 3,6290 &, 66457 & 1 & & \\
\hline Kurumsal Çevreci İmaj & 3,5075 &, 72723 &, $812^{* *}$ & 1 & \\
\hline Tekrar Satın Alma & 3,9204 &, 77863 &, $624^{* *}$ &, $557^{* *}$ & 1 \\
\hline
\end{tabular}

Korelasyon analizi sonucu değişkenler arasında 0,01 anlamlılık düzeyinde aynı yönde ilişki bulunduğu tespit edilmiştir.

\subsection{Process Makro Analizi ile Hipotez Testleri}

Havayolu firmalarında çevreci değerin kurumsal çevreci imaj ve tekrar satın almaya direkt etkisi, kurumsal çevreci imajın tekrar satın almaya direkt etkisi ve çevreci değerin tekrar satın almaya etkisinde kurumsal çevreci imajın aracı rolü nü analiz etmek için Hayes (2018) tarafından geliştirilen Process makro yöntemi kullanılmıştır. Analizlerde yöntemin şartı gereği Bootstrap tekniği ile 5000 yeniden örneklem seçeneği tercih edilmiştir. Analiz sonuçları Tablo 16'de verilmiştir.

Tablo 16: Aracılık Testine İlişkin Regresyon Analizi Sonuçları

\begin{tabular}{|l|c|c|c|c|c|c|}
\hline \multicolumn{7}{|c|}{ Sonuç Değişkenleri } \\
\hline $\begin{array}{l}\text { Tahmin } \\
\text { Değişkenleri }\end{array}$ & & M (Kurumsal Çevreci İmaj) & & \multicolumn{2}{c|}{ Y (Tekrar Satın Alma) } \\
\hline $\begin{array}{l}\text { X (Çevreci } \\
\text { Değer) }\end{array}$ & $\mathrm{a}$ & $0.8890^{* * *}$ & 0.0297 & $\mathrm{c}$ & $\mathrm{b}$ & S.H. \\
\hline $\begin{array}{l}\text { M (Kurumsal } \\
\text { Çevreci İmaj) }\end{array}$ & - & - & - & $\mathrm{b} . \mathrm{H}$. & $0.15986^{* * * *}$ & 0.0726 \\
\hline Sabit & İM & $0.2812^{* * *}$ & 0.1094 & IY & $1.2239^{* * *}$ & 0.0664 \\
\hline & & $\mathrm{R} 2=0.6601$ & & $\mathrm{R} 2=0.3965$ & 0.1573 \\
\hline & $\mathrm{F}(1 ; 463)=899,0103 ; \mathrm{P}<0.001$ & $\mathrm{~F}(2 ; 462)=151,7589 ; \mathrm{P}<0.001$ \\
\hline
\end{tabular}

$* * * \mathrm{p}<.001$

Analiz sonucunda elde edilen bulgulara göre çevreci değer, kurumsal çevreci imajı pozitif yönde anlamlı olarak etkilemektedir (B: 0.8890, \%95 CI [0.8308, 0.9473], t: 29.9835, p<0.001). P değerinin 0.001 'den küçük olmasından ve güven aralığına ait değerlerin sıfır değerini kapsamamasından beta değerinin anlamlı olduğu anlaşılmaktadır. Çevreci değer kurumsal çevreci imajın \%66,01'ünü (R2=0.6601) açıklamaktadır. Böylelikle H1 kabul edilmiştir.

Kurumsal çevreci imajın tekrar satın almayı anlamlı olarak etkilediği tespit edilmiştir (B: $0.1598, \% 95$ CI [0.0293, 0.2902], t: 2.4069, p<0.005). Çevreci değerde tekrar satın almayı anlaml olarak etkilemektedir (B:0.5886, \%95 CI [0.4459, 0.7314], t: 8.1047, p<0.001). P değerinin 0.001'den küçük olmasından ve güven aralığına ait değerlerin sıfır değerini kapsamamasından beta değerinin anlamlı olduğu anlaşılmaktadır. Kurumsal çevreci imajın ve çevreci değerin tekrar satın alma üzerindeki değişimin \%39,65'ünü (R2=.3965) açıklamaktadır. Böylelikle H2 ve H3 kabul edilmiştir.

Aracılık etkisi sonuçlarını daha kolay yorumlayabilmek için sonuçların görseli Şekil 3'de gösterilmiştir. 


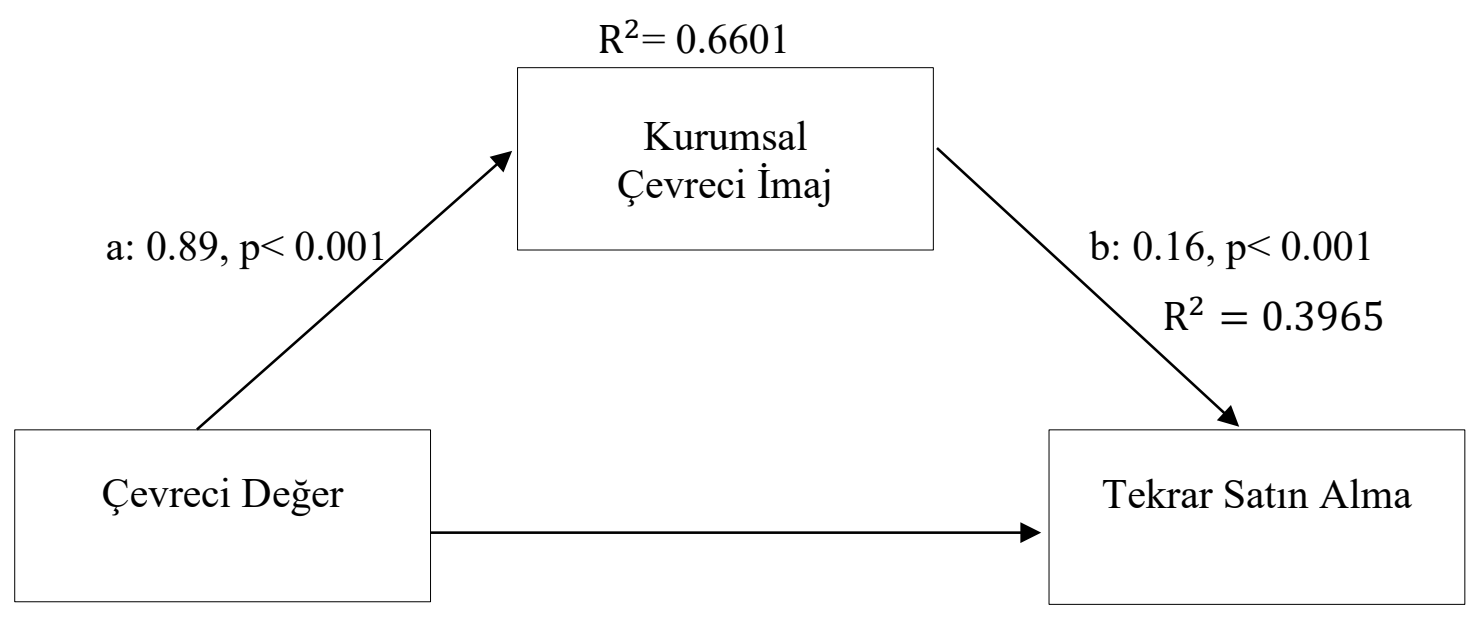

Doğrudan Etki (c'): 0.5886, p $<0.001$

Dolaylı Etki: B: 0.1420, \%95 CI [0.0417, 0.2431]

Şekil 3: Aracılık Etki Analizi Şekli

Analiz sonuçlarına göre çevreci değerin tekrar satın alma üzerinde dolaylı etkisinin anlamını olduğu dolayısıyla da kurumsal çevreci imajın çevreci değer ile tekrar satın alma arasındaki ilişkiye aracılık ettiği sonucuna ulaşılmıştır (B: 0.1420, \%95 CI [0.0417, 0.2431], p<0.001). Böylelikle H4 kabul edilmiştir. Tam standardize etki büyüklügünün $\left(\mathrm{K}^{\wedge} 2\right) 0.12$ olması etkinin orta düzeyde olduğunu göstermektedir (Gürbüz, 2019: 64).

\section{SONUÇ}

Son yıllarda çevreci uygulamalara talebin sürekli artıyor olması havayolu taşımacılığı hizmeti veren firmaları daha çevreci davranmaya zorunlu kılmıştır. Bu çalışmanın amacı çevreci değere sahip havayolu firmalarının bu değerleriyle kurumsal imaj oluşturarak tekrar satın almayı arttırabileceklerini göstermektir.

Öncelikle araştırmanın ölçeklerinin güvenirliğini test etmek için güvenirlik analizi, yapı geçerliğini sağlamak için keşfedici faktör analizi (KFA) ve doğrulayıcı faktör analizi (DFA) yapılmıştır. Havayolu firmalarında çevreci değerin kurumsal çevreci imaj ve tekrar satın almaya direkt etkisi, kurumsal çevreci imajın tekrar satın almaya direkt etkisi ve çevreci değerin tekrar satın almaya etkisinde kurumsal çevreci imajın aracı rolünü analiz etmek için Hayes (2018) tarafından geliştirilen Process makro yöntemi kullanılmıştır. Analizlerde yöntemin şartı gereği Bootstrap tekniği ile 5000 yeniden örneklem seçeneği tercih edilmiştir.

Çalışmanın analiz sonuçlar literatürle uyumlu olarak çevreci değerin kurumsal çevreci imajı (Yadav vd., 2016: Villanueva-Ponce vd., 2015; Widyastuti vd., 2019) ve tekrar satın almay1 (D’Souza vd., 2006; Ariffin vd., 2016) pozitif yönde anlamlı olarak etkilediği tespit edilmiştir (H1 ve H2 kabul edilmiştir). Beklendiği gibi yolcuların gözünde çevreci değeri olan firmaların daha yüksek kurumsal çevreci imaj gösterdiği anlaşılmıştır. Çevreci değer oluşturan havayolu firmalarının imajına bunu yansıtabilmesi önemli bir başarıdır. Ayrıca çevreci değerin tekrar satın almayı etkilemiş olması günümüzde yolcuların çevreci değerlere önem verdiğini, ekolojik kaygılara sahip olduğunu ve bu sebeple tekrar satın alma eğilimi gösterebileceğini ifade etmektedir.

Ayrıca kurumsal çevreci imajın tekrar satın almaya pozitif yönde etki ettiği bulgulanarak (Hagmann vd., 2015; Wu vd., 2018) çevreci imaja sahip olan firmalara karşı daha yüksek bir tekrar satın alma eğilimi olduğu gösterilmiştir (H3 kabul edilmiştir). Anlaşıldığı üzere, günümüzün bilinçli yolcuları çevre dostu, çevreci intibaaya sahip ve çevreci talepleri karşılayabilen firmalara karşı daha yüksek tekrar satın alma eğilimi göstermektedir. 
Son olarak çalışmada çevreci değerin tekrar satın alma üzerindeki etkisinde kurumsal çevreci imajın aracılık rolü bulunduğu gösterilmiştir (Hassan vd., 2019; Sadiartha \& Darmiyanti, 2019). Aracı değişken, bağımsız değişkenin bağımlı değişkene etkisinin bir kısmının açılandığı değişkendir. Yani havayolu firmalarında çevreci değerin tekrar satın alma üzerindeki etkisinin önemli bir kısmının kurumsal çevreci imaj ile açıklandığı bulunmuştur (H4 kabul edilmiştir).

Çalışmada bazı sınırlamalar bulunmaktadır. Öncelikle aynı tip uçaklara sahip ve aynı havaalanını kullanan havayolu firmalarının çevreci değerler konusunda ayrışması zordur. Ancak yolculara çevrecilik faaliyetleri ile ilgili verilen ön bilgilendirmeye de dayanılarak, müşterilerin ankete havayollarının çevrecilik faaliyetlerinin farkında olarak cevap verdikleri varsayılmıştır. Ayrıca ana kütlenin sadece Gaziantep ilindeki yolculardan oluşması ayrı bir sınırlamadır.

Gelecekte bu alanda yapılacak çalışmalarda öncelikle birkaç havalimanından veri toplanması ve iller bazında karşılaştırma yapılması önerilmektedir. Evrende birden fazla havaalanına ait yolcular bulunduğunda, kısmen havaalanına da bağlı olan çevreci yaklaşımlara bakış açısıyla ilgili kıyaslamalar da yapmak mümkün olacaktır. Ayrıca çevreci değerin ve kurumsal çevreci imajın tekrar satın alma dışında memnuniyet, sadakat gibi farklı bağımlı değişkenlere etkisinin incelenmesi bağımsız değişkenlerin farklı etki alanlarını anlamaya yardımcı olacaktır.

Havayolu firmalarına ise çevreci değerin yanında çevreci imaj oluşturmaları önerilmektedir. Böylelikle havayolu yolcularında tekrar satın alma eğiliminin artacağı bu çalışmada ispatlanmıştır. Çevreye karşı artan duyarlılıkla birlikte farklılaşan müşteri ihtiyaçları ve bakış açıları önümüzdeki zaman diliminde işletmelerin en önemli politika belirleme araçları haline gelecektir. Bu faktörlerleri göz önünde bulunduran işletmelerin sürdürülebilir gelişme ve büyüme göstermeleri kaçınılmazdır. Dünyada olduğu gibi Türkiye'de de son dönemlerde yükselen yolcu potansiyeline sahip olan havayolu taşımacılığında yer alan işletmelerin, bu konudaki hassasiyetlerinin artış göstermesi gerektiği elde edilen bulgularla desteklenmektedir. Ancak, uygulanan çevreci yaklaşımların müşteriye bilgilendirilmesinin yapılması konusunda eksiklikler olduğu açıktır. Firmaların bu konudaki pazarlama mesajlarını arttırarak var olan çevreci tutumlarını tüketicilere geçirmeleri gerekmektedir.

\section{KAYNAKÇA}

Ariffin, S., Yusof, J.M., Putita, L. \& Shaha, M.I.A. (2016). Factors Influencing Perceived Quality and Repurchase Intention Towards Green Products. Procedia Economics and Finance, 37, 391396.

Bayram N. (2013). Yapısal Eşitlik Modellemesine Girişi Amos Uygulamaları (2. Baskı). Bursa. Ezgi Kitabevi.

Biloslavo, R. \& Trnavcevic, A. (2009). Web Sites as Tools of Communication of a "Green"Company. Management Decision, 47(7), 1158-1173.

Bravo, R., Montaner T. \& Pina, J.M. (2009). The Role of Bank Image for Customers Versus NonCustomers. International Journal of Bank Marketing, 27(4), 315-334.

Chen, Y.S. (2008). The Driver of Green Innovation and Green Image: Green Competence. Journal of Business Ethics, 81(3), 531-540.

Chen, Y. S. (2010). The Drivers of Green Brand Equity, Green Brand Image, Green Satisfaction, and Green Trust. Journal of Business Ethics, 93(2), 307-319.

Cheng, B. \& Abdul, Z. (2013). Service Quality and the Mediating Effect of Corporate Image on the Relationship between Customer Satisfaction and Customer Loyalty in the Malaysian Hotel Industry. Gadjah Mada International Journal of Business, 15(2), 99-112.

Civelek, E. (2018). Yapısal eşitlik modellemesi metodolojisi (1. Bask1). İstanbul. Beta Yayın

D'Souza, C., Taghian, M., Lamb, P. \& Peretiatkos, R. (2006). Green Products and Corporatestrategy: An Empirical Investigation. Society and Business Review, 1(2), 146. 
DHMİ, (2019). Yolcu İstatistikleri. URL, (ET:19.02.2021).

Doszhanov, A., \& Ahmad, Z.A. (2015). Customers' Intention to Use Green Products: The Impact of Green Brand Dimensions and Green Percevied Value. EDP Sciences, 2-16.

Emgin, Ö. \& Türk, Z. (2004). Yeşil pazarlama (green marketing). Mevzuat Dergisi, 78, 11-25.

Finisterra do Paço, A. M., Raposo, M. L. B. \& Filho, W. L. (2009). Identifying the Green Consumer: A Segmentation Study. Journal of Targeting, Measurement and Analysis for Marketing, 17(1), 17-25.

Fornell, C., \& Larcker, D.F. (1981). Evaluating Structural Equation Models with Unobservable Variables and Measurement Error. Journal of Marketing Research, 18(1), 39-50.

Gürbüz, S. (2019). Sosyal Bilimlerde Arac1, Düzenleyici ve Durumsal Etki Analizleri. Ankara: Seçkin Yayınevi.

Hagmann, C, Semeijn, J. \& Vellenga, D.B. (2015). Exploring the Green Image of Airlines: Passenger Perceptions and Airline Choice. Journal of Air Transport Management, 43, 37-45.

Hassan, S., Shamsudin, M. F., Hasim, M. A., Mustapha, I., Jaafar, J., Adruthdin, K. F., \& Ahmad, R. (2019). Mediating Effect of Corporate Image and Students' Satisfaction on the Relationship Between Service Quality and Students' Loyalty in TVET HLIs. Asian Academy of Management Journal, 24, 93-105.

Hayes, A. F. (2018). Introduction to Mediation, Moderation, and Conditional Process Analysis: A Regression-Based Approach (2nd ed.). New York, NY: Guilford Press.

Hellier, P.K., Geursen, G.M., Carr, R.A. \& Rickard, J.A. (2003). Customer Repurchase Intention: A General Structural Equation Model. European Journal of Marketing, 37(11), 1762-1800.

Lam, A.Y.C., Lau, M.M. \& Cheung, R. (2016). Modelling the Relationship Among Green Perceived Value, Green Trust, Satisfaction and Repurchase Intention of Green Products. Contemporary Management Research, 12(1), 47-60.

Mayer, R. M. J., Ryley, T. \& Gillingwater, D. (2012). Passenger Perceptions of the green Image Associated with Airlines. Journal of Transport Geography, 22, 179-186.

Niu, S.Y., Liu, C.H., Chang, C.C. \& Ye, K.D. (2016). What are Passenger Perspectives Regarding Airlines' Environmental Protection? An Empirical Investigation in Taiwan. Journal of Air Transport Management, 55, 84-92.

Sadiartha, A.A.N.G. \& Darmiyanti, N.L. (2019). The Role of Corporate Image in Mediating the Effect of Service Quality on Buying Decision for a Retail Outlet in Bali. Expert Journal of Marketing, 7(1), 20-30.

Ruiz, D.T., Gremler, D.D., Washburn, J.H. \& Carrión G.C. (2008). Service Value Revisited: Specifying a Higher-Order, Formative Measure. Journal of Business Research, 61, 1278-1291.

Villanueva-Ponce, R., Garcia-Alcaraz, J.L. \& Cortes-Robles, G. (2015). Impact of Suppliers' Green Attributes in Corporate İmage and Financial Profit: Case Maquiladora Industry. Int J. Advanced Manufacturing Technology, 80, 1277-1296.

Waitz, I., Townsend, J., Cutcher-Gershenfeld, J., Greitzer, E. \& Kerrebrock, J. (2004). Report to the United States Congress Aviation and the Environment: A National Vision Statement, Framework for Goals and Recommended Actions. Cambridge: Massachusetts Institute of Technology.

Widyastuti, S., Said, M., Siswono, S. \& Firmansyah, D.A. (2019). Consumer Trust Through Green Corporate Image, Green Marketing Strategy, and Social Responsibility: A Case Study. European Research Studies Journal, 22(2), 83-99

Wu, H.C., Cheng C.C \& Ai, C.H. (2018). An Empirical Analysis of Green Switching Intentions in the Airline Industry. Journal of Environmental Planning and Management, 61(8), 1438-1468.

Yadav, R., Kumar Dokania, A. \& Swaroop Pathak, G. (2016). The Influence of Green Marketing Functions in Building Corporate Image: Evidences from Hospitality Industry in a Developing Nation. International Journal of Contemporary Hospitality Management, 28(10), 2178-2196.

Yıldız, B. \& Çiğdem, Ş. (2018). Havayolu Hizmet Kalitesinin Müşteri Memnuniyeti Üzerindeki Etkisinin Yapısal Eşitlik Modeli ile Analizi. Bingöl Üniversitesi Sosyal Bilimler Enstitüsü Dergisi, 8(16), 235-354. 